\title{
Cold subduction and the formation of lawsonite eclogite - constraints from prograde evolution of eclogitized pillow lava from Corsica
}

1. E. J. K. RAVNA',

2. T. B. ANDERSEN ${ }^{2}$,

3. L. JOLIVET ${ }^{3}$,

4. C. De CAPITANI ${ }^{4}$

Keywords: Alpine orogeny; cold subduction; Corsica; lawsonite

\begin{abstract}
A new discovery of lawsonite eclogite is presented from the Lancône glaucophanites within the Schistes Lustrés nappe at Défilé du Lancône in Alpine Corsica. The fine-grained eclogitized pillow lava and inter-pillow matrix are extremely fresh, showing very little evidence of retrograde alteration. Peak assemblages in both the massive pillows and weakly foliated inter-pillow matrix consist of zoned idiomorphic $\mathrm{Mg}$-poor (<0.8 wt\% MgO) garnet + omphacite + lawsonite + chlorite + titanite. A local overprint by the lower grade assemblage glaucophane + albite with partial resorption of omphacite and garnet is locally observed. Garnet porphyroblasts in the massive pillows are $\mathrm{Mn}$ rich, and show a regular prograde growth-type zoning with a Mn-rich core. In the interpillow matrix garnet is less manganiferous, and shows a mutual variation in $\mathrm{Ca}$ and Fe with Fe enrichment toward the rim. Some garnet from this rock type shows complex zoning patterns indicating a coalescence of several smaller crystallites. Matrix omphacite in both rock types is zoned with a rimward increase in $X_{\mathrm{Jd}}$, locally with cores of relict augite. Numerous inclusions of clinopyroxene, lawsonite, chlorite and titanite are encapsulated within garnet in both rock types, and albite, quartz and hornblende are also found included in garnet from the inter-pillow matrix. Inclusions of clinopyroxene commonly have augitic cores and omphacitic rims. The inter-pillow matrix contains cross-cutting omphacite-rich veinlets with zoned omphacite, Si-rich phengite ( $\mathrm{Si}=3.54 \mathrm{apfu}$ ), ferroglaucophane, actinolite and hematite. These veinlets are seen fracturing idiomorphic garnet, apparently without any secondary effects. Pseudosections of matrix compositions for the massive pillows, the inter-pillow matrix and the cross-cutting veinlets indicate similar $P-T$ conditions with maximum pressures of 1.9-2.6 GPa at temperatures of $335-420^{\circ} \mathrm{C}$. The inclusion suite found in garnet from the inter-pillow matrix apparently formed at pressures below 0.6-0.7 GPa. Retrogression during initial decompression of the studied rocks is only very local. Late veinlets of albite + glaucophane, without breakdown of lawsonite, indicate that the rocks remained in a cold environment during exhumation, resulting in a hairpin-shaped $P-T$ path.
\end{abstract}

\section{Introduction}

Lawsonite eclogite and blueschist are expected to be the dominant lithologies forming during subduction of oceanic crust and should therefore be fairly abundant within the Earth's crust and particularly common in exhumed subduction complexes. However, lawsonite eclogite is rare and has been described only from a few 
localities worldwide (e.g. McBirney et al., 1967; Watson \& Morton, 1969; Krogh, 1982; Caron \& Péquignot, 1986; Oh et al., 1991; Ghent et al., 1993, 2009; Shibakusa \& Maekawa, 1997; Parkinson et al., 1998; $\underline{\text { Carswell et al., }}$ 2003; Och et al., 2003; Usui et al., 2003, 2006; Altherr et al., 2004; Harlow et al., 2004; Mattinson et al., 2004; Tsujimori et al., 2005, 2006a,b; Davis \& Whitney, 2006; Zhang \& Meng, 2006; Zhang et al., 2007). Altherr et al. $\underline{(2004)}$ and Zack et al. (2004) discussed the paucity of known lawsonite eclogite complexes, which they related to the following two factors: (i) in 'normal' subduction settings lawsonite eclogite enters the subduction factory and hence is usually not exhumed (Agard et al., 2002), and (ii) in accretionary wedges where the $P-T$ path leaves the stability field of lawsonite eclogite due to heating, lawsonite eclogite is only preserved if the exhumation path is constrained to a narrow window where the terminal stability of lawsonite is not crossed. Whitney \& Davis (2006) suggested, based on observations from Sivrihisar, Turkey, that pristine lawsonite eclogite pods may represent rocks that were not deformed during exhumation. Tsujimori et al. (2006c) have used changes in inclusion mineralogy within garnet to distinguish between two types of lawsonite eclogite: L-type and E-type. L-type lawsonite eclogite contains garnet porphyroblasts that grew only within the lawsonite stability field, whereas the Etype lawsonite eclogite records maximum temperatures in the epidote stability field (Tsujimori et al., 2006c).

This paper presents data on eclogitized pillow lava and inter-pillow matrix from a new lawsonite eclogite locality in Corsica - Défilé du Lancône - showing evidence of very cold subduction-related prograde metamorphism.

\section{Geological Setting}

The island of Corsica was isolated from the main European continent and from Italy during the opening of the Liguro-Provençal basin and the northern Tyrrhenian Sea, two back-arc basins of the central Mediterranean (Rehault et al., 1984; Sartori et al., 1987; Jolivet et al., 1998). Despite significant deformation during this Oligocene extensional episode (Jolivet et al., 1991), evidence for early Alpine evolution that started in the Late Cretaceous and ended in the Early Oligocene is well preserved (Mattauer et al., 1981; Durand Delga, 1984; Fournier et al., 1991; Caron, 1994; Brunet et al., 2000). The north-eastern part of Corsica (Figs 1 \& 2 ) is mainly made up of "Schistes Lustrés", which have undergone an Alpine HPLT metamorphism of glaucophane-lawsonite type (Caron \& Péquignot, 1986). The Schistes Lustrés nappe complex consists of several thrust sheets folded and faulted in the late Cap Corse-Castagniccia antiform (Figs 1 \& 2). Eclogite and blueschist occur within both the lower ophiolitic unit and within nappes originating from the Hercynian continental basement (Lahondere, 1988). The Schistes Lustrés nappe is thrust on a large sheet of metamorphosed continental basement, the Tenda massif, where intermediate pressure blueschist parageneses have been described (Tribuzio \& Giacomini, 2002; Molli et al., 2006). All syn-high-pressure kinematic indicators show a top-to-the-west shear sense compatible with the underthrusting of the European basement below the oceanic nappes (Mattauer et al., 1981; Fournier et al., 1991). The age of the HPLT metamorphism is controversial, but ${ }^{40} \mathrm{Ar} /{ }^{39} \mathrm{Ar}$ dating of phengite indicates $\mathrm{C} .65 \mathrm{Ma}$ for the eclogitic stage and a subsequent major blueschist event from 45 Ma until 37-35 Ma in the Cap Corse and Tenda massif (Brunet et al., 2000). Older ages, between 80 and $60 \mathrm{Ma}$, are associated with the eclogitic stage (Brunet et al., 2000). The overall history of HPLT metamorphism in Corsica is thus quite similar to that of the Alps both in terms of $P-T$ conditions and timing (Agard et al., 2002). 
The Balagne nappe is the uppermost tectonic unit of the metamorphic complex and also overlies the autochthonous Hercynian basement and its cover (Fig. 1). The nappe, which occurs as two klippen, comprises a large sheet of pillow lavas in the west (Balagne ophiolite) and a mélange correlated with the Ligurian domain south of St Florent. Both of these klippen lack HPLT metamorphic rocks. The Balagne nappe was emplaced during the Eocene as attested by the presence of olistoliths in the Eocene foreland basin occurring just below the basalts (Egal, 1992).

Lawsonite eclogite has previously been described from Corsica in the Monte San Petrone Complex, further south in the Castagniccia antiform, within a meta-ophiolitic thrust-sheet consisting of serpentinized peridotite, Fe-Ti-rich and $\mathrm{Mg}-\mathrm{Cr}$-rich metagabbro, tholeiitic metabasalt and metasedimentary rocks including manganiferous metachert (Lardeaux et al., 1986). In the field, the Monte San Petrone eclogite occurs as lenses within a glaucophane schist matrix (Péquignot et al., 1984). The eclogite consists of almandine-rich garnet + omphacite + phengite + glaucophane+lawsonite+quartz+titanite + opaques (Caron et al., 1981; Caron \& Péquignot, 1986; Lardeaux et al., 1986), and a temperature of $400-450^{\circ} \mathrm{C}$ at $1.0 \mathrm{GPa}$ was estimated by Lardeaux et al. (1986). However, a recalculation of the garnet-clinopyroxene-phengite data of Caron \& Péquignot (1986) using the garnetclinopyroxene thermometer ( $\underline{\text { Ravna, 2000) }}$ ) and the garnet-clinopyroxene-phengite barometer (Ravna \& Terry, 2004) gives $\sim 390{ }^{\circ} \mathrm{C}$ at $2.05 \mathrm{GPa}$.

In Défilé du Lancône (ig. 1) blueschist of the Lower Ophiolitic unit outcrops (ㅁournier et al., 1991). This is the best-exposed section through the lower glaucophanite unit, which is composed of several sheets of massive basalt, pillow breccia and pillow lava. The main foliation is folded in a broad antiform, and a NE-SW-stretching lineation defined by the elongation of pillows and pillow fragments is observed throughout the section. Syn-highpressure kinematic indicators consistently indicate top-to-the-SW shear during the formation of the blueschist foliation that, until the discovery of the lawsonite eclogite, was thought to represent peak pressure conditions (Jolivet et al., 1991). At this locality, variably deformed pillow lava and hyaloclastite breccia consisting of glaucophane + epidote + titanite \pm garnet \pm lawsonite is common within a late foliation of chlorite + albite \pm actinolite \pm quartz (Fournier et al., 1991) , who estimated a minimum $P-T$ of $1.1 \mathrm{GPa}$ and $400^{\circ} \mathrm{C}$ for the glaucophane assemblage.

Well-preserved pillow breccia and pillow lava, the latter locally with preserved drain-out cavities, occur along the riverbed in Défilé du Lancône, immediately downstream from the water reservoir (Fig. 3a). Massive greencoloured fine-grained cores of the pillows are metamorphosed to low-temperature eclogite. The longest dimension of the eclogitized pillows ranges from 10 to $40 \mathrm{~cm}$ (Fig. 3a), and they consist of a green, very fine-grained massive rock with tiny euhedral garnet evenly distributed throughout. Locally, somewhat coarser grained, weakly foliated zones with aggregates of white mica form matrix material between pillows and pillow fragments. Seams of glaucophane-rich material are locally present, especially in the deformed pillows and meta-hyaloclastite, the latter occurring between the pillows and fragmented pillows and along pillow margins (ig. $3 \mathrm{~b})$. 


\section{Analytical Procedures}

Mineral analyses were performed by electron microprobe (Cameca SX-100) at Dionýz Štúr Institute of Geology in Bratislava. Analytical conditions for the EMPA were $15 \mathrm{kV}$ accelerating voltage and $20 \mathrm{nA}$ beam current, with a peak counting time of $20 \mathrm{~s}$ and a beam diameter of 2-10 $\mu \mathrm{m}$. Raw counts were corrected using a PAP routine. Mineral standards (Si, Ca: wollastonite; Na: albite; K: orthoclase; Fe: fayalite, Mn: rhodonite), pure element oxides $\left(\mathrm{TiO}_{2}, \mathrm{Al}_{2} \mathrm{O}_{3}, \mathrm{Cr}_{2} \mathrm{O}_{3}\right.$ and $\left.\mathrm{MgO}\right)$ were used for calibration. Supplementary analyses were performed using a JEOL840 Scanning Electron Microscope with an EDAX unit at the Department of Medical Biology, University of Tromsø. The ZAF matrix correction and optimized SEC factors using various natural standards were used. Counting time was $200 \mathrm{~s}$ with an accelerating voltage of $20 \mathrm{kV}$ and a sample current of $6 \mathrm{nA}$. Totals of anhydrous minerals are normalized to $100.0 \mathrm{wt} \%$, amphibole to $98.0 \%$ and chlorite to $86.0 \mathrm{wt} \%$.

Garnet formulae are normalized to 12 oxygen and clinopyroxene to four cations, with $\mathrm{Fe}^{3+}$ calculated by charge balance (Droop, 1987). Phengite is normalized to 11 oxygen, chlorite to 28 oxygen, and lawsonite and titanite to eight and five oxygen respectively. Amphibole analyses were normalized according to the scheme recommended by the IMA (Leake et al., 1997), using the spreadsheet AMPH-CLASS (Esawi, 2004). Selected mineral analyses are given in Tables $1-3$.

\section{Petrography and mineral chemistry}

The massive pillows generally consist of very fine-grained eclogite (Fig. 3). Of 10 samples, three representative samples were chosen for our investigation. Samples from massive pillows and the weakly foliated phengitebearing layers are described, and mineral analyses of principal minerals from three samples are presented. Samples COR-1 and COR-1' are from a massive pillow fragment, whereas samples COR-4 are from the weakly foliated variety. Sample COR-1 is from the core and COR-1' from the faint bluish margin of the same pillow fragment.

Both the massive eclogite (Fig. 4a) and the foliated variety (ig. 4b) have small idiomorphic garnet (5 modal \%; up to $200 \mu \mathrm{m}$ across) set in a matrix of omphacite (55-60 modal \%; up to $70 \times 200 \mu \mathrm{m}$ across), lathlike lawsonite (20-30 modal \%; up to $20 \times 300 \mu \mathrm{m}^{2}$ across), chlorite (7-15\%) and titanite (3-5\%). Calcite occurs in tiny veinlets. In the foliated inter-pillow matrix, cross-cutting veinlets consisting of omphacite (80\%), phengite (15\%) with minor glaucophane $(<5 \%)$ and hematite is common (Fig. $4 \mathrm{~d}-\mathrm{g}$ ). Locally, these veinlets also cross-cut fractured garnet (Fig. 4f), but there does not seem to be any resorption of garnet in contact with the veins. Garnet commonly contains numerous solid inclusions. Inclusions of lawsonite, chlorite, titanite and clinopyroxene are present in all samples (Fig. $4 \mathrm{a}-\mathrm{C})$. In addition, inclusions of albite, hornblende and quartz are found in garnet in the foliated rock. Glaucophane has been found as a secondary matrix phase in the marginal part of the massive pillow fragment (sample COR-1') where it occurs together with albite against slightly resorbed garnet (Fig. $4 \mathrm{~g})$. In the massive eclogite, omphacite and lawsonite are randomly oriented (Fig. 4a). In foliated eclogite matrix omphacite and lawsonite show a weak preferred orientation. 


\section{Garnet}

Garnet is rich in almandine, grossular and spessartine, and low in pyrope (Table 1), similar to that described by Caron et al. (1981). It is chemically zoned, in sample COR-1 ranging from $\mathrm{Gr}_{29} \mathrm{Sp}_{27} \mathrm{Alm}_{42} \mathrm{Py}_{2}$ (core) to $\mathrm{Gr}_{33} \mathrm{Sp}_{15} \mathrm{Alm}_{49} \mathrm{Py}_{3}$ (rim). Garnet in sample COR-4 is more Ca- and Fe-rich and lower in Mn, ranging from $\mathrm{Gr}_{44} \mathrm{Sp}_{6} \mathrm{Alm}_{49} \mathrm{Py}_{2}$ (core) to $\mathrm{Gr}_{32} \mathrm{Sp}_{8} \mathrm{Alm}_{59} \mathrm{Py}_{2}$ (rim). Zoning profiles appear to be continuous in both samples (Fig. 5a,b), except for some irregularly zoned garnet from COR-4 (Fig. 4b).

\section{Clinopyroxene}

Clinopyroxene analyses are recalculated to four cations and six oxygen with estimation of $\mathrm{Fe}^{3+}$ by charge balance (Droop, 1987). Clinopyroxene in the studied samples shows a large compositional variation (Table 2 ; Fig. 6 ).

Generally, clinopyroxene inclusions in garnet are less sodic than the matrix omphacite in all samples. Low-Na and Al-Ti-rich clinopyroxene (augite) with up to $4.6 \mathrm{wt} \% \mathrm{Al}_{2} \mathrm{O}_{3}$ and $3.95 \mathrm{wt} \% \mathrm{TiO}_{2}$ occurs as cores of inclusions in all samples, commonly mantled and rimmed by successively more jadeite-rich omphacite (Fig. 4c; Table 2). Matrix clinopyroxene is also zoned with augitic cores and increasing jadeite content toward the rim. Omphacite in the cross-cutting veinlets in sample COR-4 have distinctly lower Mg \# (46.7-55.4) than those in the matrix (63.270.8). They also show an opposite rimward zoning from $\mathrm{Jd}_{23} \mathrm{Aeg}_{21}(\mathrm{Mg} \#=55)$ to $\mathrm{Jd}_{11} \mathrm{Aeg}_{14}(\mathrm{Mg} \#=47)$.

\section{Other minerals}

Phengite in the cross-cutting veins of sample COR-4 is virtually unzoned, with a Si-content of 3.56 apfu based on 11 oxygen and $\mathrm{Mg \#}=66$ assuming all $\mathrm{Fe}$ as $\mathrm{Fe}^{2+}(\underline{\text { Table } 3})$. Lawsonite has $\mathrm{Fe}_{2} \mathrm{O}_{3}$ content in the range 0.50$1.18 \%$, inclusions in garnet having the lower values. Chlorite is present as inclusions in garnet and as a matrix phase, with Mg\# ranging from 65 (inclusion in garnet) to 68 (matrix) in COR-1, and Mg\# = 50 in COR-4. Titanite is relatively Al-poor $\left(X_{\mathrm{Al}}=0.04\right)$. Albite included in garnet in sample COR-4 and as a secondary matrix phase in sample COR-1' is relatively pure ( $A b_{97}$ and $A b_{100}$ respectively). Small inclusions of edenitic hornblende with $\mathrm{Ca}_{\mathrm{B}}=1.70,(\mathrm{Na}+\mathrm{K})_{\mathrm{A}}=0.51, \mathrm{Fe}^{3+} /\left(\mathrm{Fe}^{3+}+\mathrm{Al}\right)=0.24$ and $\mathrm{Mg} \#=60$ were identified in the core of a garnet in sample COR-4. Blue amphibole occurring in the omphacite-rich veins in sample COR-4 has $\mathrm{Fe}^{3+} /\left(\mathrm{Fe}^{3+}+\mathrm{Al}\right)=0.21$ and $\mathrm{Mg \#}=48$, and is classified as ferroglaucophane. Secondary blue amphibole associated with albite in sample COR-1' is glaucophane with $\mathrm{Fe}^{3+} /\left(\mathrm{Fe}^{3+}+\mathrm{Al}\right)=0.00$ and $\mathrm{Mg} \#=62$.

\section{Metamorphic evolution and conditions}

\section{Pre-metamorphic relics (0)}

Ca-Al-Ti-rich cores (augite) of clinopyroxene inclusions in garnet and in the matrix most likely represent relict magmatic pyroxene crystallized from the basaltic precursor. Similar compositions are reported from relict magmatic cores of porphyroblastic Na-pyroxene in eclogitic metabasites from Sivrihisar in the Tavsanlı Zone, Turkey (Cetinkaplan et al., 2008).

\section{Pre-eclogitic metamorphic stages (I)}


The earliest metamorphic minerals recorded in the lawsonite eclogite from Défilé du Lancône are found as inclusions within garnet and as low-jadeite cores of matrix clinopyroxene. Inclusions of Ca-rich and $\mathrm{TiO}_{2}$-poor clinopyroxene, hornblende, chlorite, albite and titanite probably represent early (low- $P$ ) metamorphic phases. Overgrowths of successively more sodic pyroxene on Na-poor pyroxene indicate that the continuous reaction

$$
\text { - } \mathrm{Di}+\mathrm{Ab}=\mathrm{Omph}+\mathrm{Qtz}_{(1)}
$$

produced more omphacitic pyroxene by consumption of albite during increasing pressure. The observed zoning in matrix omphacite in the same sample supports this interpretation. The zoning patterns of garnet from the two different lithologies studied here, with cores strongly enriched in Mn (COR-1) or Ca (COR-4) are also consistent with initial growth at low $P-T$ conditions. Thus, the observed inclusion suite of albite, quartz, hornblende and lowto high-Na clinopyroxene in garnet in sample COR-4 apparently represents different transient $P-T$ conditions during early subduction. A true equilibrium assemblage among these phases is therefore difficult to suggest. The irregular zoning pattern observed in some garnet in sample COR-4 apparently indicates that they formed by coalescence and overgrowth of several smaller garnet during increasing $P-T$.

A precise estimate of $P-T$ for these early stages of subduction is not straight forward. Reaction (1) is likely to have proceeded during this time until albite was entirely consumed. The low modal content and Mn- and Ca-rich and $\mathrm{Mg}$-poor composition of garnet points to very low temperatures.

\section{Lawsonite eclogite stage (II)}

The Fe-Mg distribution among garnet and omphacite is commonly used as a temperature monitor, and the garnet-clinopyroxene Fe-Mg exchange thermometer (Ravna, 2000) gives temperatures in the range of 350$400{ }^{\circ} \mathrm{C}$ at a nominal pressure of $2.0 \mathrm{GPa}$, using rim compositions of garnet and matrix omphacite.

The cross-cutting omphacite-rich veinlets with phengite, ferroglaucophane and hematite in sample COR-4 were obviously emplaced as a result of influx of Na-rich fluids along fractures after the growth of garnet (Fig. 4f) , but at still high- $P$ conditions as evidenced by high jadeite content of omphacite, stability of ferro-glaucophane and the high Si-content of phengite. The zoning of vein omphacite with decreasing jadeite content from core to rim suggests that the fluid influx continued at decreasing pressure conditions or, alternatively, at changing composition of the fluid. The significantly lower $\mathrm{Mg}$ number of the vein clinopyroxene compared with the matrix pyroxene clearly indicates different origins.

\section{Lawsonite blueschist stage (III)}

The assemblage glaucophane + albite, observed very locally in sample COR-1', post-dates the lawsonite eclogite stage and constrains the metamorphic conditions to $<450{ }^{\circ} \mathrm{C}$ and $<1.5 \mathrm{GPa}$ according to the metamorphic facies grid of Bousquet et al. (1997).

\section{Post-blueschist stages}

As no greenschist overprint was observed in the samples reference is made to Miller \& Cartwright (2006) who presented data on greenschist facies metamorphism and almost monomineralic albite veins from the same 
locality at Défilé du Lancône. They estimated that the greenschist assemblages formed at $510{ }^{\circ} \mathrm{C}$ and $0.6 \mathrm{GPa}$, whereas they concluded that the albite veins were formed at $478 \pm 31^{\circ} \mathrm{C}$ and $0.37 \pm 0.14 \mathrm{GPa}$ after the regional greenschist facies retrogression.

\section{$P-T$ estimates from isochemical phase diagrams}

To further constrain the metamorphic evolution and $P-T$ conditions for the Défile du Lancône lawsonite eclogites isochemical $P-T$ phase diagrams were constructed for three bulk compositions. The bulk compositions $(\underline{\text { Figs } 7-9})$ were obtained by EDS area scans of the matrix of samples COR-1 and COR-4, respectively, as well as of the omphacite-rich veinlets in sample COR-4.

For the first two compositions the system $\mathrm{SiO}_{2}-\mathrm{TiO}_{2}-\mathrm{Al}_{2} \mathrm{O}_{3}-\mathrm{FeO}-\mathrm{MgO}-\mathrm{CaO}-\mathrm{Na}_{2} \mathrm{O}$ and for the veinlets the system $\mathrm{SiO}_{2}-\mathrm{Al}_{2} \mathrm{O}_{3}-\mathrm{FeO}-\mathrm{MgO}-\mathrm{CaO}-\mathrm{Na}_{2} \mathrm{O}-\mathrm{K}_{2} \mathrm{O}-\mathrm{O}_{2}$, all with excess $\mathrm{H}_{2} \mathrm{O}$ were investigated. Clarke et al. (2006) pointed out that unusually high water contents are demanded by lawsonite assemblages. The program Theriak-Domino (de Capitani \& Brown, 1987) with the Berman database JUN92.bs and the activity models therein were used. The modelling does not include Mn, which principally will be partitioned into garnet and thus increase the stability field of garnet to lower temperatures and pressures.

For sample COR-1 the calculated stability field of the matrix assemblage garnet-omphacite-lawsonite-chloritetitanite within a wedge-shaped field occurs between $\sim 1.9$ and $2.75 \mathrm{GPa}$ at $350{ }^{\circ} \mathrm{C}$ with a maximum thermal stability of $\sim 470^{\circ} \mathrm{C}$ at $2.3 \mathrm{GPa}(\underline{\text { Fig. } 7})$. At lower pressures amphibole is stable, and at higher pressures ilmenite becomes an additional phase. Neither of these phases has been observed. Albite is stable in this composition only up to $\sim 0.6 \mathrm{GPa}$, garnet (Ca-rich) appears at pressures slightly below $0.5 \mathrm{GPa}$ and lawsonite appears at $\sim 1.1 \mathrm{GPa}$, all at $400{ }^{\circ} \mathrm{C}$.

Sample COR-4 has the same matrix assemblage, which is stable within a relatively large field ranging from $\sim 340^{\circ} \mathrm{C}$ and 1.3-2.6 GPa to a thermal maximum of $490-500^{\circ} \mathrm{C}$ at 2.0-2.1 GPa (Fig. 8). In this composition garnet is stable over most of the diagram. Lawsonite appears at $\sim 1.1 \mathrm{GPa}$ and albite disappears at $\sim 0.7 \mathrm{GPa}$ at $400{ }^{\circ} \mathrm{C}$. The assemblage albite + Ca-clinopyroxene + hornblende + titanite, which is included in garnet cores, is stable together with garnet and paragonite (not observed) at pressures below $\sim 0.7 \mathrm{GPa}$ at $400{ }^{\circ} \mathrm{C}$.

The omphacite-rich veinlets consisting of omphacite + phengite + glaucophane + hematite + quartz are stable between 1.05-2.4 GPa at $330^{\circ} \mathrm{C}$ and 1.9-2.5 GPa, 410-420 ${ }^{\circ} \mathrm{C}$ (Fig. 9). The assemblage omphacite + phengite + glaucophane + hematite may also coexist with coesite at pressures above 2.4-2.5 GPa. Quartz/coesite has not been observed, but the estimated content of free silica in our calculations is less than $2 \%$.

To summarize, the results of the thermodynamic modelling of the three different bulk compositions indicate that the observed peak mineral assemblages were all stable within a wedge-shaped window ranging from $\sim 340{ }^{\circ} \mathrm{C}$ and 1.9-2.6 GPa to $415^{\circ} \mathrm{C}$ and $2.2 \mathrm{GPa}$. 


\section{Discussion}

The lawsonite eclogite from Défilé du Lancône shows evidence of extremely low temperatures, as exemplified by low modal content of garnet, typical low- $T$ composition of garnet (low Mg, high $\mathrm{Mn}$ and $\mathrm{Ca}$ ), large compositional variations of clinopyroxene and garnet. These features may also be indicative of rapid subduction. There is no evidence of breakdown of lawsonite during decompression, clearly indicating that the terminal stability limit of lawsonite was not crossed, and that the low P/T persisted during exhumation.

The earliest observed phase occurring as inclusions in garnet and as cores of matrix clinopyroxene is Ti-Al-rich augite assumed to represent relicts of the magmatic stage. During the early stages of subduction $\mathrm{Ca}$ - and $\mathrm{Mn}$-rich garnet, diopsidic clinopyroxene, Ca-amphibole, chlorite, albite, titanite and probably epidote and paragonite (not observed) became stable at pressures below $\sim 0.7 \mathrm{GPa}$, probably at temperatures of $\sim 350{ }^{\circ} \mathrm{C}$. Continued subduction resulted in the consumption of the lower pressure assemblages, giving rise to the peak assemblage garnet-omphacite-lawsonite-chlorite-titanite, representing lawsonite eclogite facies. The thermodynamic modelling using Theriak-Domino constrains the peak $P-T$ conditions to $340-415^{\circ} \mathrm{C}$ and $1.9-2.6 \mathrm{GPa}$, which actually is in agreement with the garnet-clinopyroxene Fe-Mg thermometric estimates. These peak conditions are close to, and even enter, the coesite stability field and the so-called "forbidden zone" of Liou et al. (2000), which indicates a regime of rapid subduction. Rapid subduction and burial of the HPLT rocks in Corsica is further supported by the evidence of subduction-related seismic activity recorded by blueschist facies pseudotachylites found in both gabbro and spinel-peridotite in the Cima di Gratera area (see Fig. 1; Austrheim \& Andersen, 2004; Andersen \& Austrheim, 2006). These rocks preserve evidence of high strength during subduction, another argument for the very cold geotherm (Andersen et al., 2008).

It is, however, important to stress that the accuracy of the $P-T$ estimates obtained here are hampered by large uncertainties. In the present samples the pyrope content of garnet is very low and far outside the range used for the calibration of the garnet-clinopyroxene $\mathrm{Fe}-\mathrm{Mg}$ thermometer, and the obtained temperatures are at least $200^{\circ} \mathrm{C}$ lower that the lowermost temperature $\left(600^{\circ} \mathrm{C}\right)$ used for this calibration (Ravna, 2000). Thus, these temperature estimates obtained here should only be regarded as indicative of very low temperatures. Likewise, in the thermodynamic modelling $\mathrm{Mn}$ as a major component in garnet has been omitted, and the results are also strongly dependent on the quality of the thermodynamic data at such low temperatures. In addition, the observed incomplete reactions of even pre-metamorphic phases will probably have some influence on the effective bulk composition, and thus the final output. Nevertheless, the obtained results are not unrealistic. More important than the 'absolute' $P-T$ conditions is the sequential metamorphic evolution which clearly demonstrates a cold regime during subduction as well as initial exhumation. If these rocks ever entered the area defined as the 'forbidden zone', or were subjected to coesite stability conditions cannot be evaluated here.

The prograde metamorphic evolution of the Défilé du Lancône lawsonite eclogite bears similarities to lawsonite eclogite described from the Motagua fault zone, Guatemala (Harlow et al., 2004; Tsujimori et al., 2005, 2006b), where the basalt-eclogite transformation may have occurred at temperatures as low as $\sim 300^{\circ} \mathrm{C}$ in a cold subduction zone with the apparent direct formation of lawsonite eclogite without passing through the blueschist 
facies. These authors suggested that dehydration of chlorite + albite + lawsonite \pm pumpellyite to form garnet + omphacite within the lawsonite field may be more effective than the glaucophane-forming reaction during subduction. In our samples, however, the thermodynamic modelling indicates that glaucophane was not a stable phase at any $P-T$ conditions due to bulk compositional constraints. Glaucophane was only stabilized in the extreme Na-rich composition of the omphacite-rich veinlets of sample COR-4, and in the very local domains of retrograde glaucophane + albite.

The preservation of lawsonite indicates that the low geothermal gradient prevailed during at least the initial stages of exhumation, following more or less the same path as during subduction, similar to the path proposed by Cetinkaplan et al. (2008) for the lawsonite eclogite in Sivrihisar, Tavşanlı Zone in Turkey. This suggests that material flowing up along the subduction channel was refrigerated by continued subduction of cold material. The estimated peak pressures of 1.9-2.6 GPa are much higher than those recorded for the main lawsonite blueschist facies (top-to-the-south-west shear) event, which is well developed elsewhere in the area and most probably related to retrogression during exhumation. The main thrusting phase was thus contemporaneous with the upward motion of the HP units within the subduction complex. This shows that the Lancône ophiolitic material was not significantly deformed until after it reached its maximum depth and that the first deformation was associated with exhumation. Continued retrogression into greenschist facies conditions has been thoroughly studied (Fournier et al., 1991; Jolivet et al., 1998; Miller \& Cartwright, 2006) and the suggested retrograde $P-T$ paths from Fournier et al. (1991) and Jolivet et al. (1998) are shown in Fig. 10. The latter part of exhumation has been attributed to the post-orogenic extension that started at c. 33-32 Ma and led to the opening of the LiguroProvençal Basin and the Tyrrhenian Sea (Jolivet et al., 1991; Brunet et al., 2000). Miller \& Cartwright (2006) suggested estimates of $510^{\circ} \mathrm{C}$ at $0.6 \mathrm{GPa}$ for the greenschist facies overprint, which requires a late thermal pulse. However, their estimate may be too high for greenschist facies.

In the model presented here we assume, supported by the numerical modelling of $P-T$-depth conditions in subduction channels (Gerya et al., 2002; Yamato et al., 2007), that pressure can be converted to depth according to $P \pm 10 \%=\rho g h$ ( $\rho$, density; $g$, gravitational acceleration; $h$, burial depth).

Finally, we propose a possible exhumation scenario (ig. 10). The finding of very high pressure in Défilé du Lancône forces us to reconsider previously proposed schemes (Fournier et al., 1991), that did not have to accommodate such large depths of burial. Our reconstruction starts in the latest Cretaceous when Ligurian oceanic crust and perhaps also the leading edge of the European continental margin (the youngest oceanic sediments date to late Cretaceous) had entered the subduction zone, and an accretionary complex had already developed above it at the expense of Ligurian oceanic domain. At this time a piece of partly eclogitized oceanic crust detached from the subducting lithosphere at $\sim 80 \mathrm{~km}$ depth and began its exhumation path along the subduction channel. The main top-to-the-west deformation recorded in the eclogite dates from the Palaeocene and Eocene when it had reached the blueschist domain. From the Eocene onward the Adria plate to the east started subducting and a progressive reorganization of the subduction polarity ensued orogen-parallel extension and arc bending forced by slab tearing and toroidal flow at the junction between the Alps and Apennines (Vignaroli et al., 2008). This situation developed during the Eocene and culminated in the middle Eocene with the 
emplacement of superficial parts of the accretionary complex onto the foreland basin to the west. Units undergoing exhumation continued their way up in the subduction channel and eventually reached the accretionary complex, the last units to be involved in thrusting being the Tenda massif and Corte slices. At 33 Ma the regime of subduction changed in the Mediterranean region as a whole and slab retreat started (Jolivet \& Faccenna, 2000), leading to the reactivation of major thrusts as extensional shear zones and normal faults that completed the exhumation of the metamorphic domain. Finally, the extensional deformation migrated eastward and Corsica became more or less stable.

\section{Acknowledgements}

Grants covering the analytical expenses of E. Krogh Ravna were received from the Norwegian Academy of Science and Letters through 'Nansenfondet og de dermed forbundne fond'. A Centre of Excellence grant from the Norwegian Research Council to the PGP financed T.B. Andersen. The technical support by T.I. Eilertsen at the Electron Microscopy Lab, Department of Medical Biology, University of Tromsø, and the staff at the Electron Microprobe Lab at Dionýz Štúr Institute of Geology in Bratislava are much appreciated. Thorough reviews by $\mathrm{T}$. Rivers and J.X. Zhang greatly improved the paper.

\section{References}

- $\quad$ Agard, P., Monie, P., Jolivet, L. \& Goffé, B., 2002. Exhumation of the Schistes Lustres complex: in situ laser probe ${ }^{40} \mathrm{Ar} /{ }^{39} \mathrm{Ar}$ constraints and implications for the Western Alps. Journal of Metamorphic Geology, 20, 599618.

- $\quad$ Altherr, R., Topuz, G., Marschall, H., Zack, T. \& Ludwig, T., 2004. Evolution of a tourmaline-bearing lawsonite eclogite from the Elekdag area (Central Pontides, N Turkey): evidence for infiltration of slab-derived B-rich fluids during exhumation. Contributions to Mineralogy and Petrology, 148, 409-425.

- $\quad$ Andersen, T.B. \& Austrheim, H., 2006. Fossil earthquakes recorded by pseudotachylytes in mantle peridotite from the Alpine subduction complex of Corsica. Earth and Planetary Science Letters, 242, 1-2.

- $\quad$ Andersen, T.B., Mair, K., Austrheim, H., Podladchikov, Y.Y. \& Vrijmoed, J.C., 2008. Stress-release in exhumed intermediate-deep earthquakes determined from ultramafic pseudotachylyte. Geology, 36, 995-998.

- $\quad$ Austrheim, H. \& Andersen, T. .B., 2004. Pseudotachylytes from Corsica: fossil earthquakes from a subduction complex. Terra Nova, 16, 193-197.

- Bousquet, R., Goffé, B., Henry, P., Le Pichon, X. \& Chopin, C., 1997. Kinematic, thermal and petrological model of the Central Alps: lepontine metamorphism in the upper crust and eclogitization of the lower crust. Tectonophysics, 273, 105-127.

- $\quad$ Brunet, C., Monie, P., Jolivet, L. \& Cadet, J.P., 2000. Migration of compression and extension in the Tyrrhenian Sea, insights from ${ }^{40} \mathrm{Ar} /{ }^{39} \mathrm{Ar}$ ages on micas along a transect from Corsica to Tuscany. Tectonophysics, 321 , 127-155. 
- De Capitani, C. \& Brown, T.H., 1987. The computation of chemical equilibria in complex systems containing non-ideal solutions. Geochimica et Cosmochimica Acta, 51, 2639-2652.

- $\quad$ Caron, J.M., 1994. Metamorphism and deformation in Alpine Corsica. Schweizerische Mineralogische und Petrographische Mitteilungen, 74, 105-114.

- $\quad$ Caron, J.M. \& Péquignot, G., 1986. The transition between blueschists and lawsonite-bearing eclogites based on observations from Corsican metabasalts. Lithos, 19, 205-218.

- $\quad$ Caron, J.M., Kienast, J.R. \& Triboulet, C., 1981. High-pressure-low-temperature metamorphism and polyphase Alpine deformation at Sant'Andrea di Cotone (Eastern Corsica, France). Tectonophysics, 78, 419-451.

- $\quad$ Carswell, D.A., Tucker, R.D., O’Brien, P.J. \& Krogh, T.E., 2003. Coesite micro-inclusions and the U/Pb age of zircons from the Hareidland eclogite in the Western Gneiss Region of Norway. Lithos, 67, 181-190.

- Çetinkaplan, M., Candan, O., Oberhänsli, R. \& Bousquet, R., 2008. Pressure-temperature evolution of lawsonite eclogite in Sivrihisar; Tavşanlı Zone - Turkey. Lithos, 104, 12-32,

- $\quad$ Clarke, G.L., Powell, R. \& Fitzherbert, J.A., 2006. The lawsonite paradox: a comparison of field evidence and mineral equilibria modeling. Journal of Metamorphic Geology, 24, 715-725,

- Davis, P.B. \& Whitney, D.L., 2006. Petrogenesis of lawsonite and epidote eclogite and blueschist, Sivrihisar, Turkey. Journal of Metamorphic Geology, 24, 823-849,

- Droop, G.T.R., 1987. A general equation for estimating $\mathrm{Fe}^{3+}$ concentrations in ferromagnesian silicates and oxides from microprobe analyses using stoichiometric criteria. Mineralogical Magazine, 51, 431-435.

- Durand Delga, M., 1984. Principaux traits de la Corse alpine et corrélation avec les Alpes ligures. Memorie della Societá Geologica Italiana, 28, 285-329.

- Egal, E., 1992. Structures and tectonic evolution of the External Zone of Alpine Corsica. Journal of Structural Geology, 14, 1215-1228.

- $\quad$ Esawi, E.K., 2004. AMPH-CLASS: an Excel spreadsheet for the classification and nomenclature of amphiboles based on the 1997 recommendations of the International Mineralogical Association. Computers \& Geosciences, 30, 753-760.

- $\quad$ Fournier, M., Jolivet, L., Goffé, B. \& Dubois, R., 1991. The Alpine Corsica metamorphic core complex. Tectonics, 10, 1173-1186.

- $\quad$ Gerya, T.V., Stöckhert, B. \& Perchuk, A.L., 2002. Exhumation of high-pressure metamorphic rocks in a subduction channel: a numerical simulation. Tectonics, 21, 1-15.

- $\quad$ Ghent, E.D., Stout, M.Z. \& Erdmer, P., 1993. Pressure-temperature evolution of lawsonite-bearing eclogites, Pinchi Lake, British Columbia. Journal of Metamorphic Geology, 11, 279-290.

- $\quad$ Ghent, E.D., Tinkham, D. \& Marr, R., 2009. Lawsonite eclogites from the Pinchi Lake area, British Columbia new $P-T$ estimates and interpretation. Lithos, 109, 248-253, 
- Harlow, G.E., Hemming, S.R., Avé Lallemant, H.G., Sisson, V.B. \& Sorensen, S.S., 2004. Two high-pressurelow-temperature serpentinite-matrix melange belts, Motagua fault zone, Guatemala: a record of Aptian and Maastrictian collisions. Geology, 32, 17-20.

- Jolivet, L. \& Faccenna, C., 2000. Mediterranean extension and the Africa-Eurasia collision. Tectonics, 19, 1095-1106.

- Jolivet, L., Daniel, J.M. \& Fournier, M., 1991. Geometry and kinematics of extension in Alpine Corsica. Earth and Planetary Science Letters, 104, 278-291.

- Jolivet, L., Faccenna, C., Goffé, B. et al. , 1998. Midcrustal shear zones in postorogenic extension: example from the northern Tyrrhenian Sea. Journal of Geophysical Research, 103, 12123-12160.

- Krogh, E.J., 1982. Metamorphic evolution of Norwegian country-rock eclogites, as deduced from mineral inclusions and compositional zoning in garnets. Lithos, 15, 305-321.

- Lahondere, D., 1988. Eclogitic Metamorphism in Farinoles orthogneisses and ophiolitic metabasites (Northern Corsica, France). Bulletin de la Societé Géologique de France, 4, 579-585.

- $\quad$ Lardeaux, J.-M., Caron, J.-M., Nisio, P., Péquignot, G. \& Boudeulle, M., 1986. Microstructural criteria for reliable thermometry in low-temperature eclogites. Lithos, 19, 187-203.

- $\quad$ Leake, B.E., Woolley, A.R., Arps, C.E.S. et al. , 1997. Nomenclature of Amphiboles: report of the subcommittee on amphiboles of the International Mineralogical Association, commission on new minerals and mineral names. Canadian Mineralogist, 35, 219-246.

- $\quad$ Liou, J.G., Hacker, B.R. \& Zhang, R.Y., 2000. Into the forbidden zone. Science, 287, 1215-1216,

- $\quad$ Mattauer, M., Faure, M. \& Malavieille, J., 1981. Transverse lineation and large-scale structures related to Alpine obduction in Corsica. Journal of Structural Geology, 3, 401-409.

- Mattinson, C.G., Zhang, R.Y., Tsujimori, T. \& Liou, J.G., 2004. Epidote-rich talc-kyanite-phengite eclogites, Sulu terrane, eastern China: $P-T-f\left(O_{2}\right)$ estimates and the significance of the epidote-talc assemblage in eclogite. American Mineralogist, 89, 1772-1783.

- $\quad$ McBirney, A., Aoki, K.I. \& Bass, M.N., 1967. Eclogites and jadeite from Motagua Fault Zone Guatemala. American Mineralogist, 52, 908-918.

- $\quad$ Miller, J.A. \& Cartwright, I., 2006. Albite vein formation during exhumation of high-pressure terranes: a case study from Alpine Corsica. Journal of Metamorphic Geology, 24, 409-428.

- Molli, G., Tribuzio, R. \& Marquer, D., 2006. Deformation and metamorphism at the eastern border of the Tenda Massif (NE Corsica): a record of subduction and exhumation of continental crust. Journal of Structural Geology, 28, 1748-1766.

- $\quad$ Och, D.J., Leitch, E.C., Caprarelli, G. \& Watanabe, T., 2003. Blueschist and eclogite in tectonic melange, Port Macquarie, New South Wales, Australia. Mineralogical Magazine, 67, 609-624. 
- $\quad$ Oh, C.W., Liou, J.G. \& Maruyama, S., 1991. Low-temperature eclogites and eclogitic schists in Mn-rich metabasites in Ward Creek, California - Mn and Fe effects on the transition between blueschist and eclogite. Journal of Petrology, 32, 275-302.

- $\quad$ Parkinson, C.D., Miyazaki, K., Wakita, K., Barber, A.J. \& Carswell, D.A., 1998. An overview and tectonic synthesis of the pre-Tertiary very-high-pressure metamorphic and associated rocks of Java, Sulawesi and Kalimantan, Indonesia. Island Arc, 7, 184-200.

- Péquignot, G., Lardeaux, J.M. \& Caron, J.M., 1984. Recristallisation d'éclogites de basse température dans les métabasaltes corses. C.R. Academie des Sciences Paris, 299 II (13), 871-874.

- Ravna, E.K., 2000. The garnet-clinopyroxene Fe+2+Mg geothermometer: an updated calibration. Journal of Metamorphic Geology, 18, 211-219.

- Ravna, E.J.K. \& Terry, M.P., 2004. Geothermobarometry of UHP and HP eclogites and schists - an evaluation of equilibria among garnet-clinopyroxene-kyanite-phengite-coesite/quartz. Journal of Metamorphic Geology, 22, 579-592.

- $\quad$ Rehault, J.P., Boillot, G. \& Mauffret, A., 1984. The western Mediterranean Basin geological evolution. Marine Geology, 55, 447-477.

- $\quad$ Sartori, R., Mascle, G. \& Amaudric du Chaffaut, S., 1987. A review of circum-Tyrrhenian regional geology. Proceedings Initial Reports Ocean Drilling Program (Part A), 107, 37-63.

- Shibakusa, H. \& Maekawa, H., 1997. Lawsonite-bearing eclogitic metabasites in the Cazadero area, northern California. Mineralogy and Petrology, 61, 163-180.

- $\quad$ Tribuzio, R. \& Giacomini, F., 2002. Blueschist facies metamorphism of peralkaline rhyolites from the Tenda crystalline massif (northern Corsica): evidence for involvement in the Alpine subduction event? Journal of Metamorphic Geology, 20, 513-526.

- Tsujimori, T., Liou, J.G., \& Coleman, R.G., 2005. Coexisting retrograde jadeite and Omphacite in a jadeitebearing lawsonite eclogite from the Motagua Fault Zone, Guatemala. American Mineralogist, 90, 836-842.

- Tsujimori, T., Matsumoto, K., Wakabayashi, J. \& Liou, J.G., 2006a. Franciscan eclogite revisited: reevaluation of the P-T evolution of tectonic blocks from Tiburon Peninsula, California, USA. Mineralogy and Petrology, 88, 243-267.

- Tsujimori, T., Sisson, V.B., Liou, J.G., Harlow, G.E. \& Sorensen, S.S., 2006b. Petrologic characterization of Guatemalan lawsonite eclogite: Eclogitization of subducted oceanic crust in a cold subduction zone. UltrahighPressure Metamorphism: Deep continental subduction. Geological Society of America Special Papers 403, pp.147-168 (eds Hacker, B.R., McClelland, W.C. \& Liou, J.G.).

- Tsujimori, T., Sisson, V.B., Liou, J.G., Harlow, G.E. \& Sorensen, S.S., 2006c. Very-low-temperature record of the subduction process: a review of worldwide lawsonite eclogites. Lithos, 92, 609-624. 
- Usui, T., Nakamura, E., Kobayashi, K., Maruyama, S. \& Helmstaedt, H., 2003. Fate of the subducted Farallon plate inferred from eclogite xenoliths in the Colorado Plateau. Geochimica et Cosmochimica Acta, 67, A505.

- Usui, T., Nakamura, E. \& Helmstaedt, H., 2006. Petrology and geochemistry of eclogite xenoliths from the Colorado Plateau: implications for the evolution of subducted oceanic crust. Journal of Petrology, 47, 929-964.

- Vignaroli, G., Faccenna, C., Jolivet, L., Piromallo, C. \& Rossetti, F., 2008. Subduction polarity reversal at the junction between the Western Alps and the Northern Apennines, Italy. Tectonophysics 450, 34-50, doi:

- Watson, K.D. \& Morton, D.M., 1969. Eclogite inclusions in kimberlite pipes at Garnet Ridge, northeastern Arizona. American Mineralogist, 54, 267-285.

- Whitney, D.L. \& Davis, P.B., 2006. Why is lawsonite eclogite so rare? Metamorphism and preservation of lawsonite eclogite, Sivrihisar, Turkey. Geology, 34, 473-476,

- Yamato, P., Agard, P., Burov, E., Le Pourhiet, L., Jolivet, L. \& Tiberi, C., 2007. Burial and exhumation in subduction wedge: mutual constraints from thermo-mechanical modelling and natural $P-T-t$ data (Schistes Lustrés, W. Alps). Journal of Geophysical Research - Solid Earth, 112, B07410,

- $\quad$ Zack, T., Rivers, T., Brumm, R. \& Kronz, A., 2004. Cold subduction of oceanic crust: implications from a lawsonite eclogite from the Dominican Republic. European Journal of Mineralogy, 16, 909-916.

- Zhang, J.X. \& Meng, F.C., 2006. Lawsonite-bearing eclogites in the north Qilian and north Altyn Tagh: evidence for cold subduction of oceanic crust. Chinese Science Bulletin, 51, 1238-1244.

- Zhang, J.X., Meng, F.C. \& Wan, Y.S., 2007. A cold Early Palaeozoic subduction zone in the North Qilian Mountains, NW China: petrological and U-Pb geochronological constraints. Journal of Metamorphic Geology, 25, 285-304. 


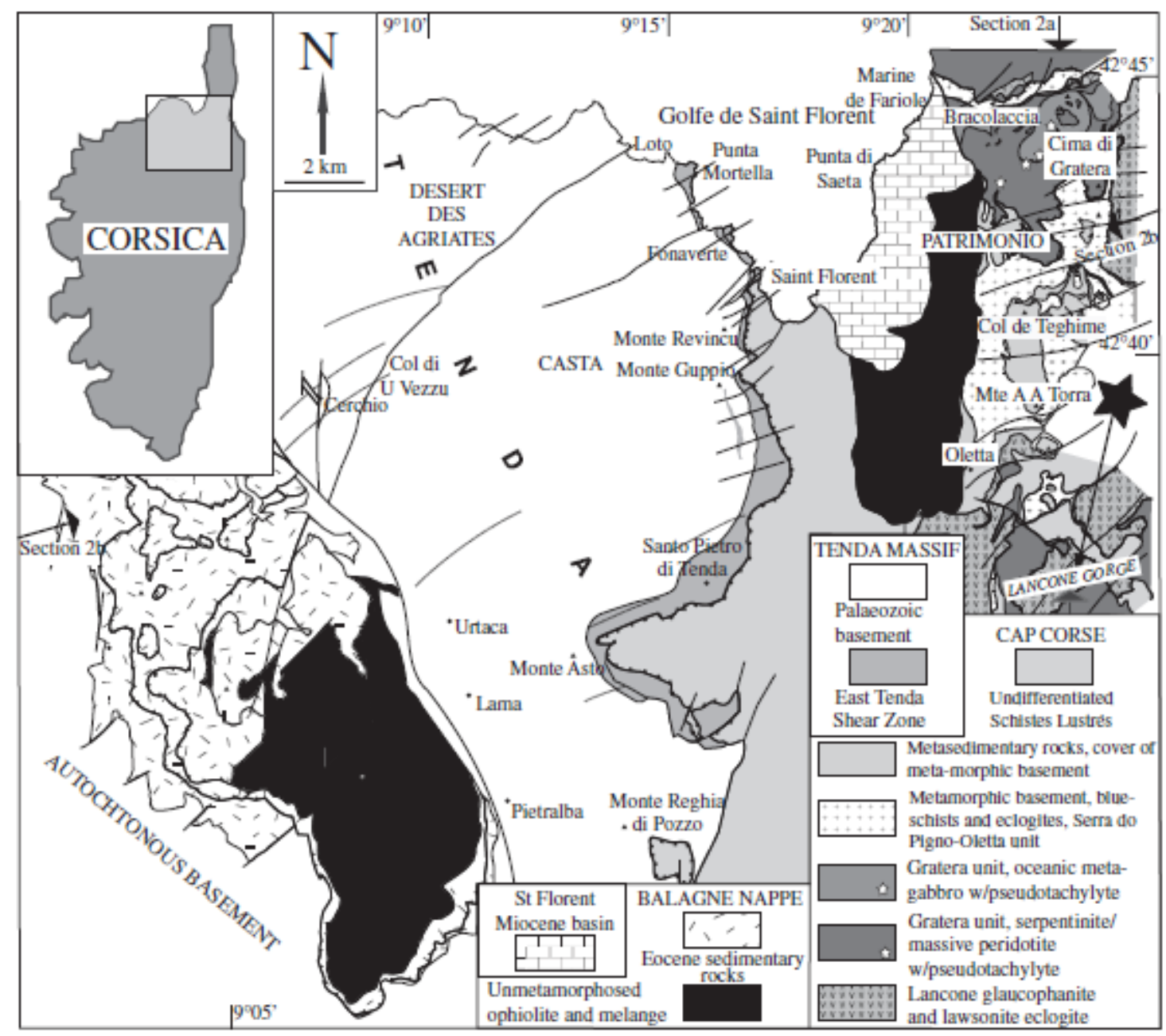

Fig. 1. Geological map of northern Corsica (see inset map for location) showing the main Alpine tectonic units and location of the new lawsonite eclogite locality in De'file' du Lanco^ ne (marked with star). Notice the location of subduction-related pseudotachylytes north of Patrimonio.

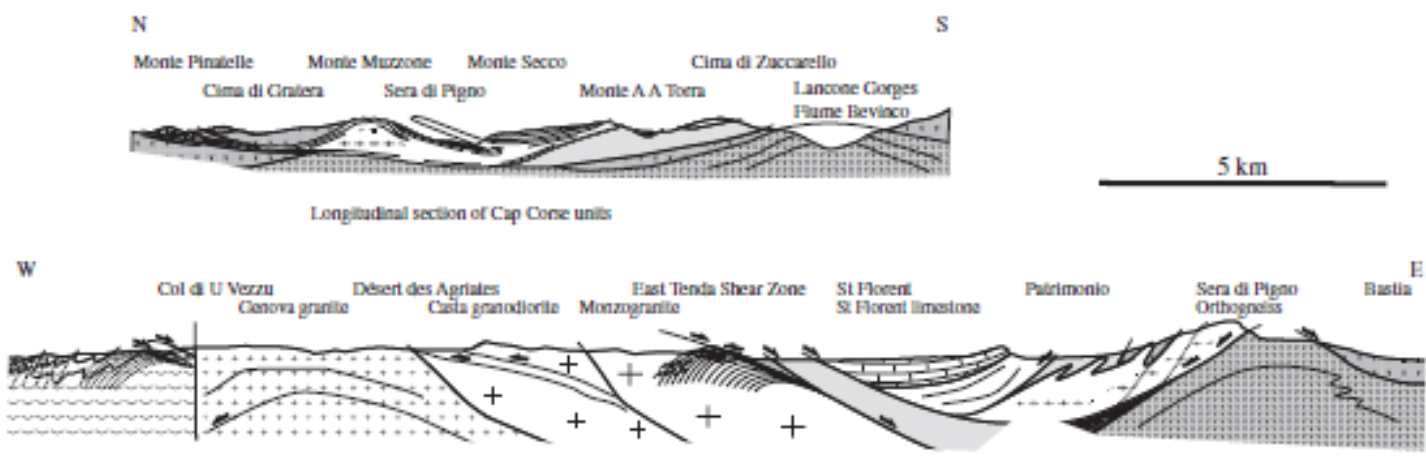

Tenda masali ant Cap Corse

Fig. 2. N-S (a) and E-W (b) cross-sections of northern Corsica (modified from Jolivet et al., 1998) showing the main tectonic units and the locations of blueschist to eclogite facies pseudotachylytes and the eclogite facies rocks in the area. Notice that the De'file' du Lanco` ne lawsonite eclogite locality is positioned at a low structural level. 

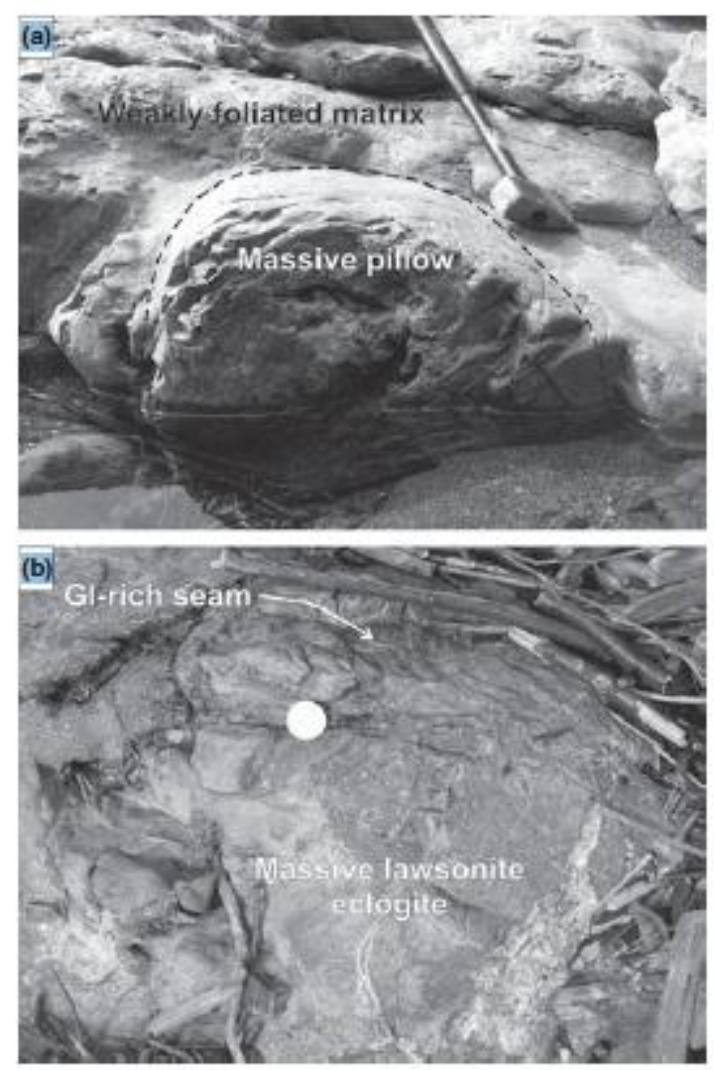

Fig. 3. Eclogitized pillow lava along the riverbed of De'file' du Lanco^ ne. (a) A well-preserved pillow with internal drainout, convex upward cavity. Notice that the pillows have blue outer margins due to the superimposed blueschist facies metamorphism. (b) Details of a massive eclogitized pillow with a thin seam of glaucophanite. 

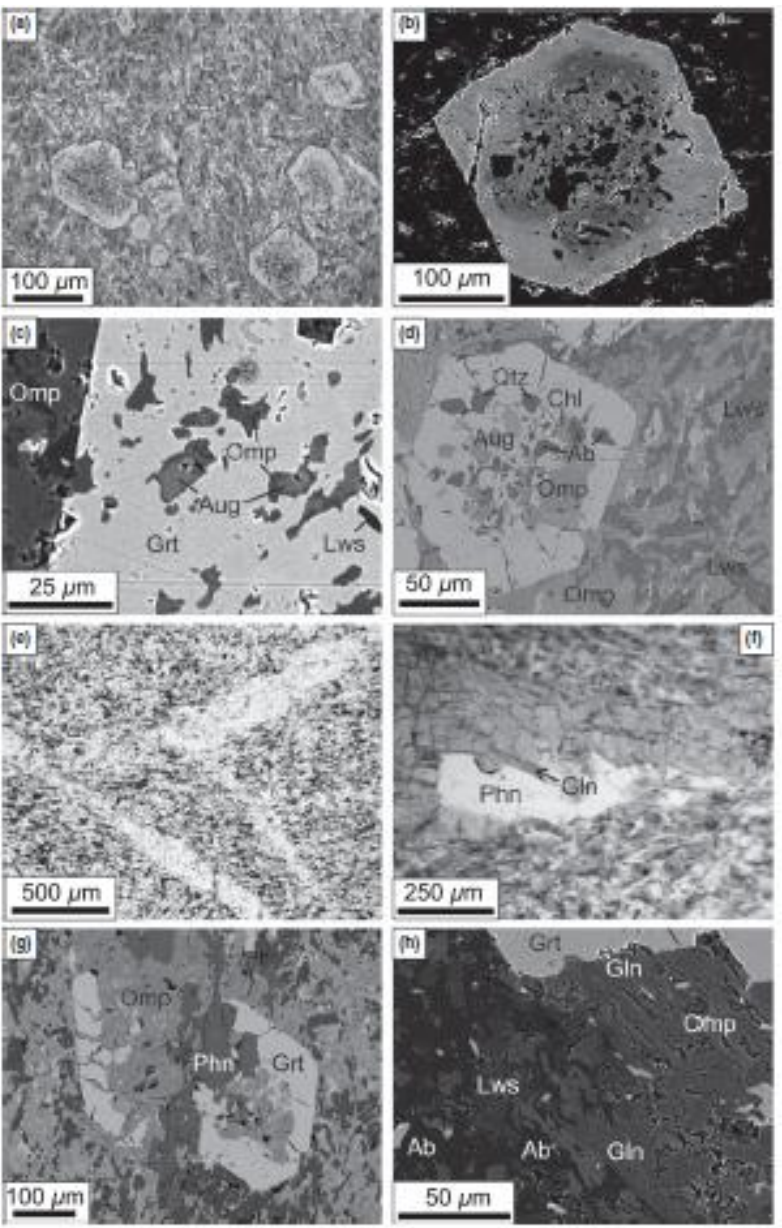

Fig. 4. (a) Massive lawsonite eclogite with euhedral garnet in a matrix of randomly oriented omphacite and lawsonite (light grey laths). Sample COR-1. (b) BSE image of euhedral garnet showing complex compositional variation due to reciprocal concentrations of $\mathrm{Fe}$ and $\mathrm{Ca}$. Areas with dark grey colour have lower $\mathrm{Fe} / \mathrm{Ca}$ ratio. Dark inclusions are mainly omphacite and lawsonite. Sample COR-4. (c) BSE image of euhedral garnet with numerous inclusions of augite, omphacite, albite, chlorite and quartz. Matrix consists of omphacite, lawsonite and minor titanite. Sample COR-4. (d) BSE image of euhedral garnet with inclusions of lawsonite and augite overgrown by omphacite. Matrix consists of omphacite, lawsonite and minor titanite. Sample COR-1. (e) Veinlets of omphacite + phengite + minor glaucophane cross-cutting the weakly foliated matrix of sample COR-4. (f) Details of omphacite-rich veinlet with phengite and glaucophane. Sample COR-4. (g) Omphacite-rich veinlet cross-cutting a fractured garnet. Sample COR-4. (f) Incipient retrogression with secondary glaucophane and albite and partly resorption of garnet. Sample COR-1 $\$$. 

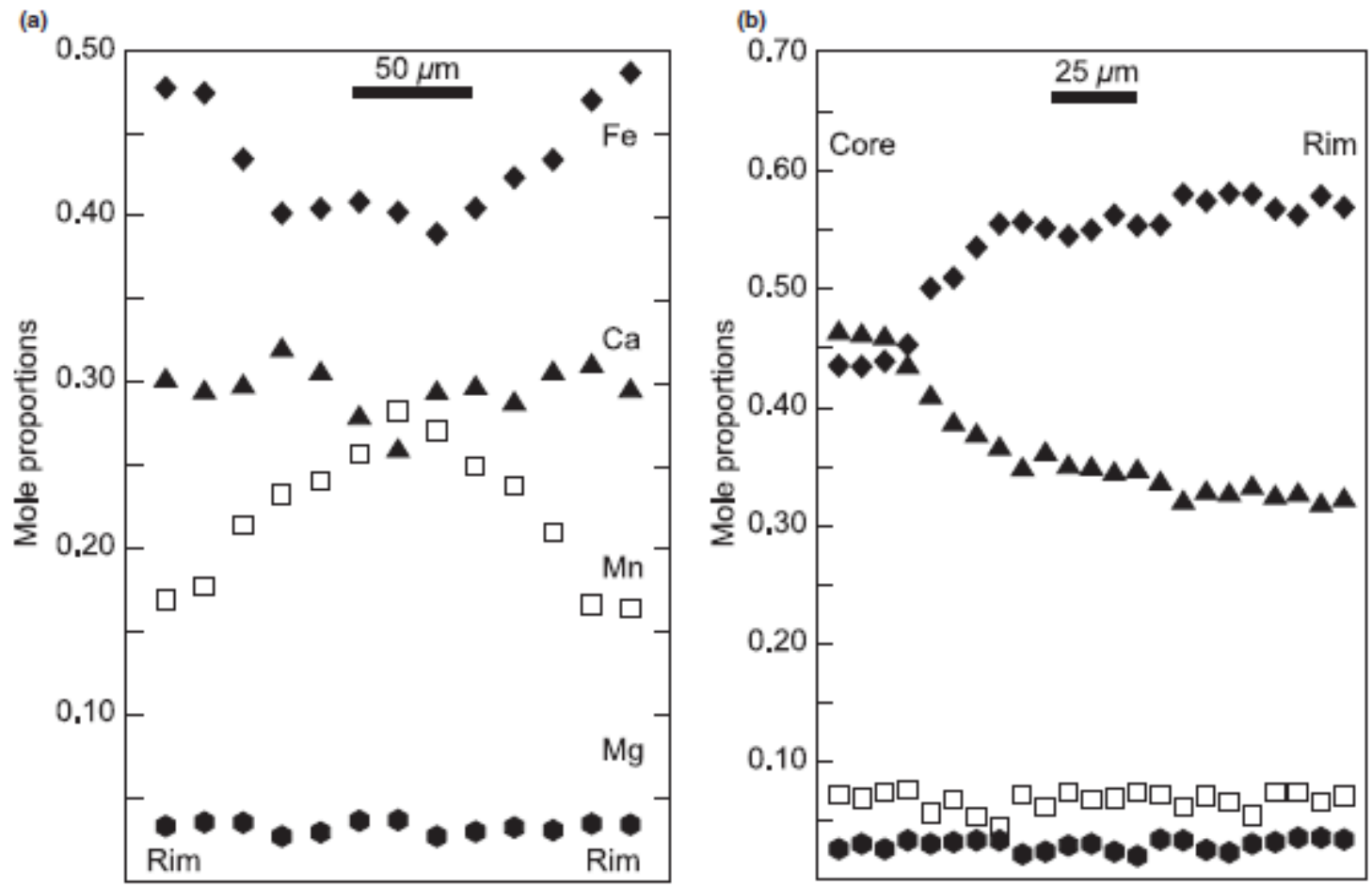

Fig. 5. Zoning profile across euhedral garnet in sample COR-1 (a) and COR-4 (b). The garnet from the latter sample did not show any evidence of coalescence of several smaller garnet as that shown in Fig. 4c.

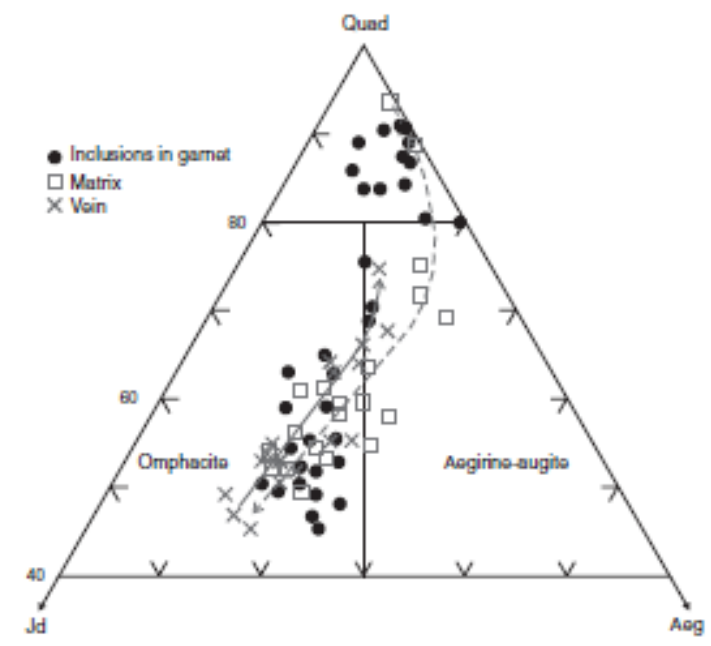

Fig. 6. Compositional variations of clinopyroxene from sample COR-4. Quad = quadrilateral components (Ca, Mg and $\mathrm{Fe}$ ) in clinopyroxene. Stippled and solid arrows indicate compositional evolution of matrix and vein clinopyroxenes respectively. 


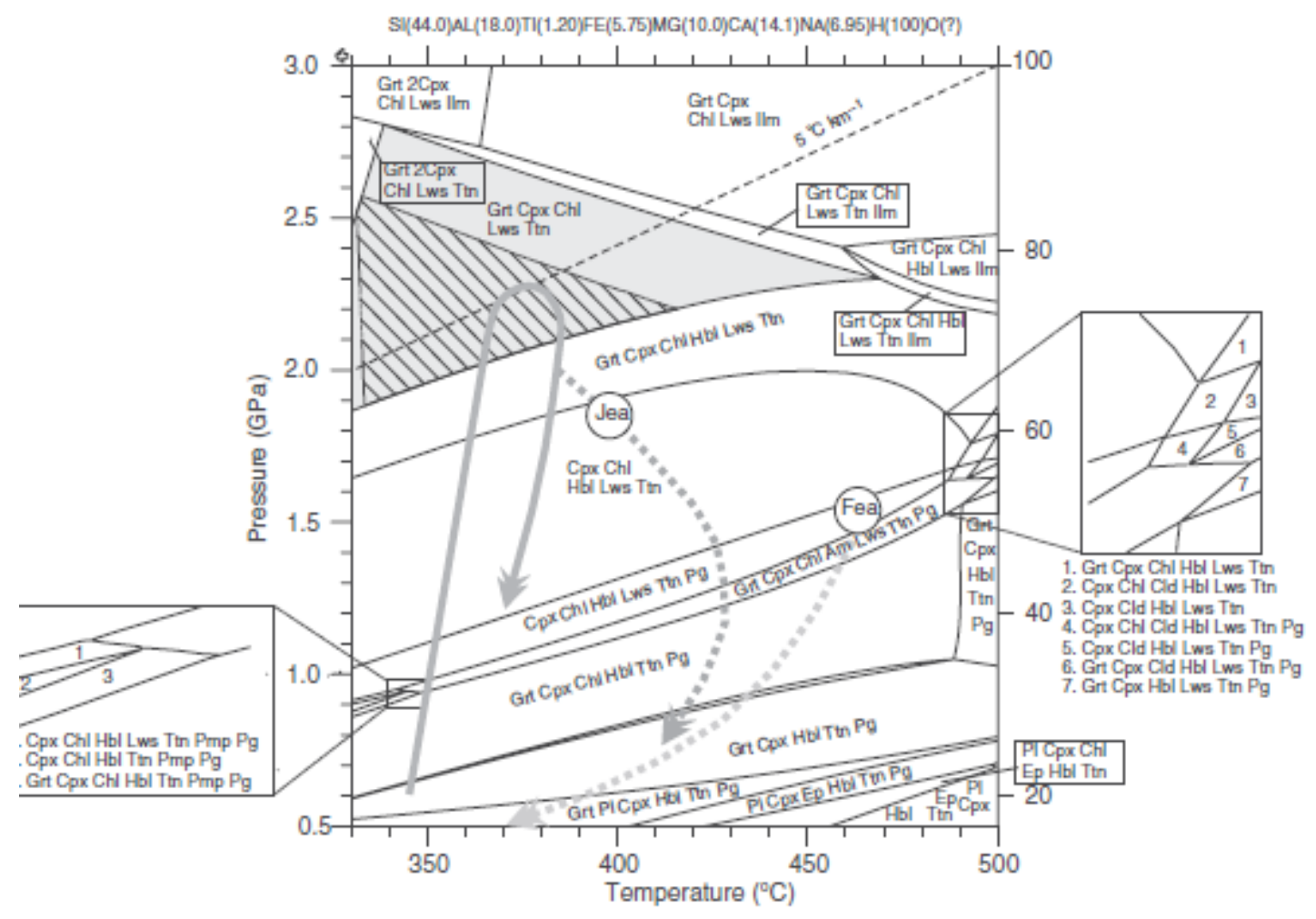

Fig. 7. Isochemical P-T phase diagram showing the stability fields for mineral assemblages in sample COR-1, calculated using Theriak-Domino. See text for discussion. Hatched area marks overlapping P-T conditions for peak assemblages in all three bulk compositions. Note that in the upper left corner are two small fields with two coexisting clinopyroxenes. A tentative P-T path of the De'file' du Lanco^ ne lawsonite eclogite based on textural observations and thermodynamic modelling is shown (solid hairpin arrow). Alternative retrograde P-T paths are taken from Fournier et al., 1991 (Fea) and Jolivet et al., 1998 (Jea). 


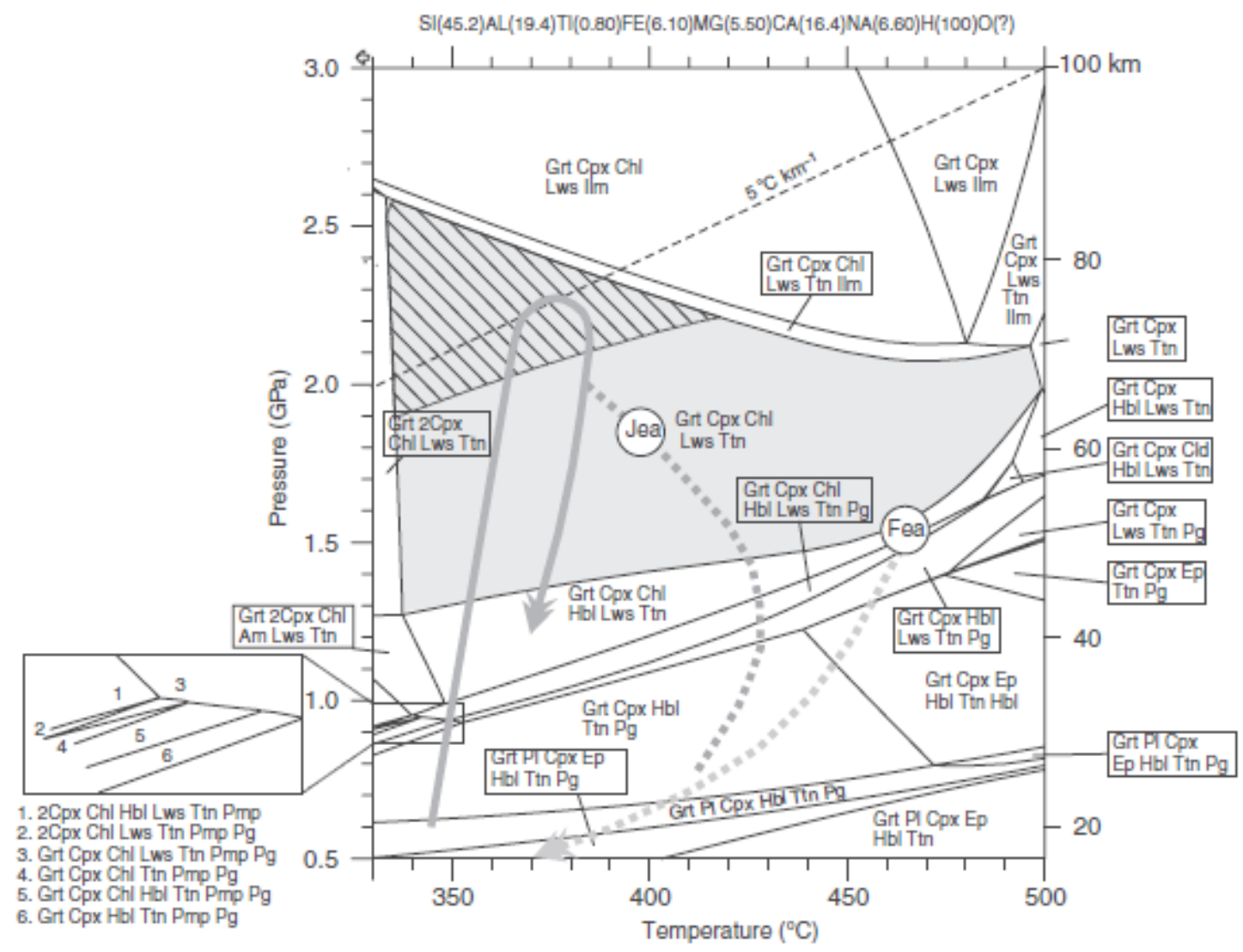

Fig. 8. Isochemical P-T phase diagram showing the stability fields for mineral assemblages in sample COR-4 matrix, calculated using Theriak-Domino. See text for discussion. Note that at 0.9-2.6 GPa and $<340$ _C two coexisting clinopyroxenes can be stable. 


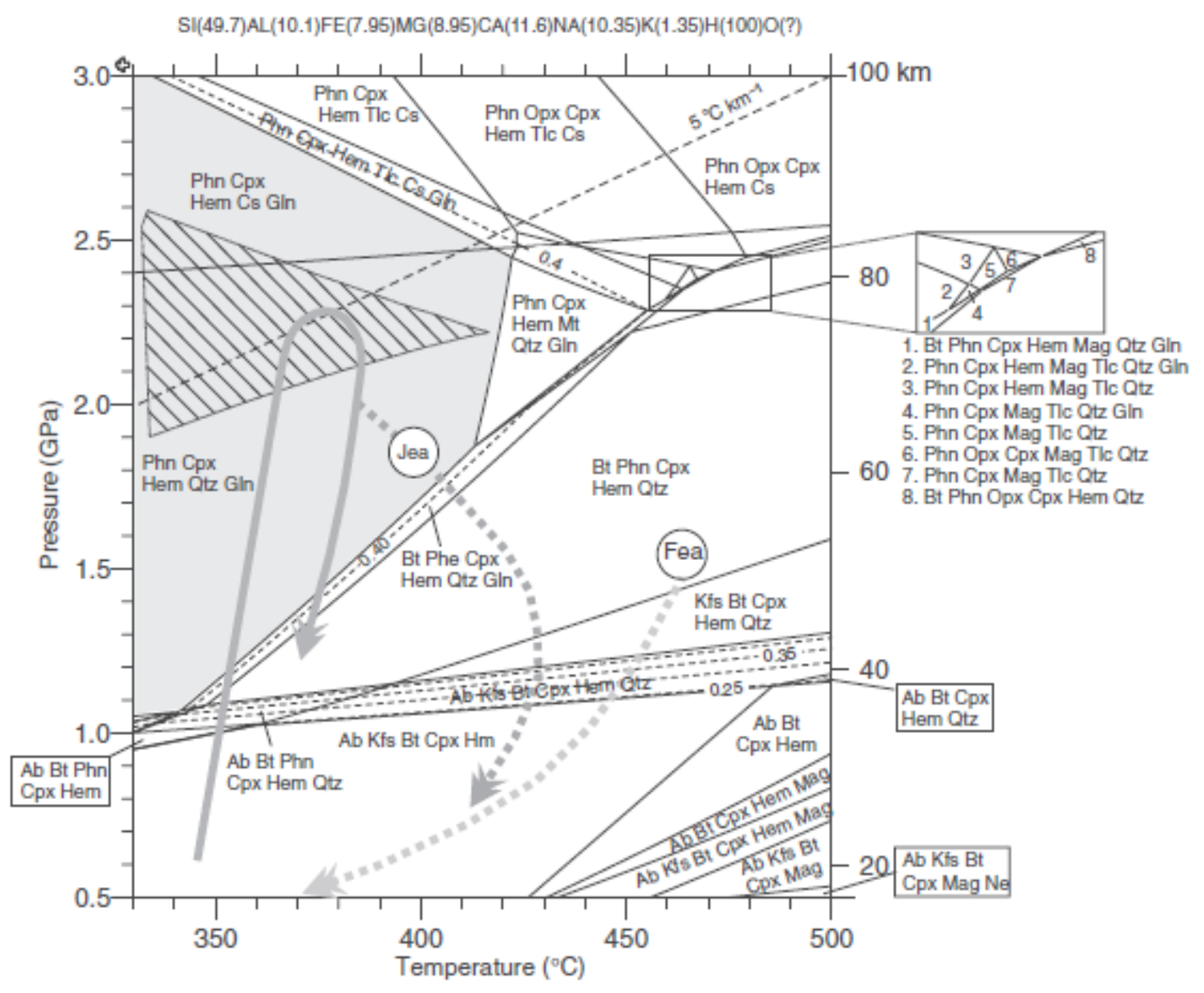

Fig. 9. Isochemical P-T phase diagram showing the stability fields for mineral assemblages in omphacite-rich veins, sample COR-4, using Theriak-Domino. Contours for jadeite content of clinopyroxene are shown as stippled lines. See text for discussion. 


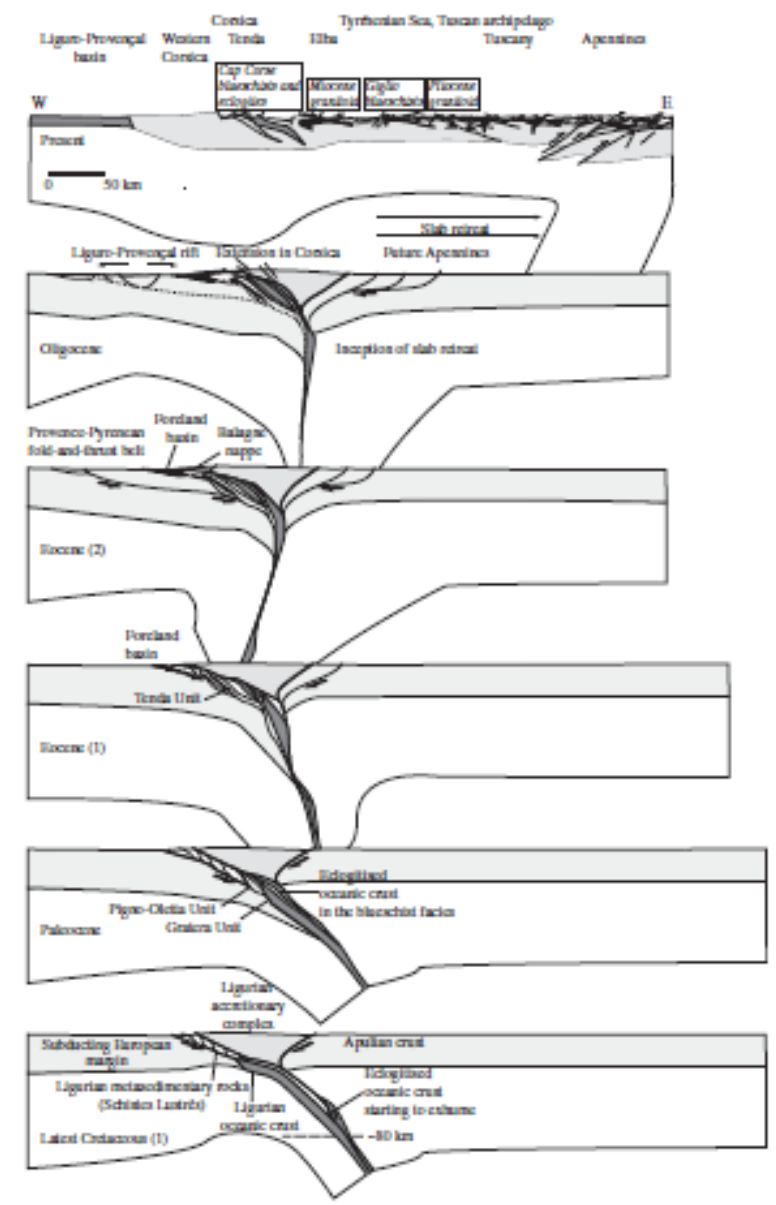

Fig. 10. Model of tectonic evolution of the Alpine LTHP metamorphic complexes Corsica (modified from Jolivet et al., 1998), where the new P-T data from lawsonite eclogites in De'file' du Lanco` ne have been incorporated. See text for discussion and details. 
Table 1. Selected garnet analyses.

\section{Sample}

\begin{tabular}{lll}
\hline COR-1 COR-1' COR-4 & CO
\end{tabular}

\begin{tabular}{llllll}
\hline Core & Rim & Core & Rim & Core & Rim
\end{tabular}

$\mathrm{SiO}_{2}$

$37.83 \quad 37.94$

37.71

38.22

38.11

37.53

$\mathrm{Al}_{2} \mathrm{O}_{3}$

20.49

20.95

20.63

20.82

21.00

20.40

$\mathrm{TiO}_{2}$

0.32

0.12

0.24

0.17

0.10

0.12

$\mathrm{Cr}_{2} \mathrm{O}_{3}$

0.08

0.07

0.04

0.05

0.04

0.01

$\mathrm{FeO}$

19.15

22.53

20.38

22.48

22.72

26.59

$\mathrm{MnO}$

12.06

6.78

9.87

4.97

2.64

3.56

$\mathrm{MgO}$

0.60

0.80

0.56

0.72

0.40

0.51

$\mathrm{CaO}$

10.55

11.61

11.10

13.53

15.93

11.16

101.07

100.81

100.53

100.96

100.94

99.89

12 oxygen

Si

3.01

3.01

3.01

3.01

3.00

3.02

Al

1.92

1.96

1.94

1.94

1.95

1.93

$\mathrm{Ti}$

0.02

0.01

0.01

0.01

0.01

0.01 
Table 1. Selected garnet analyses.

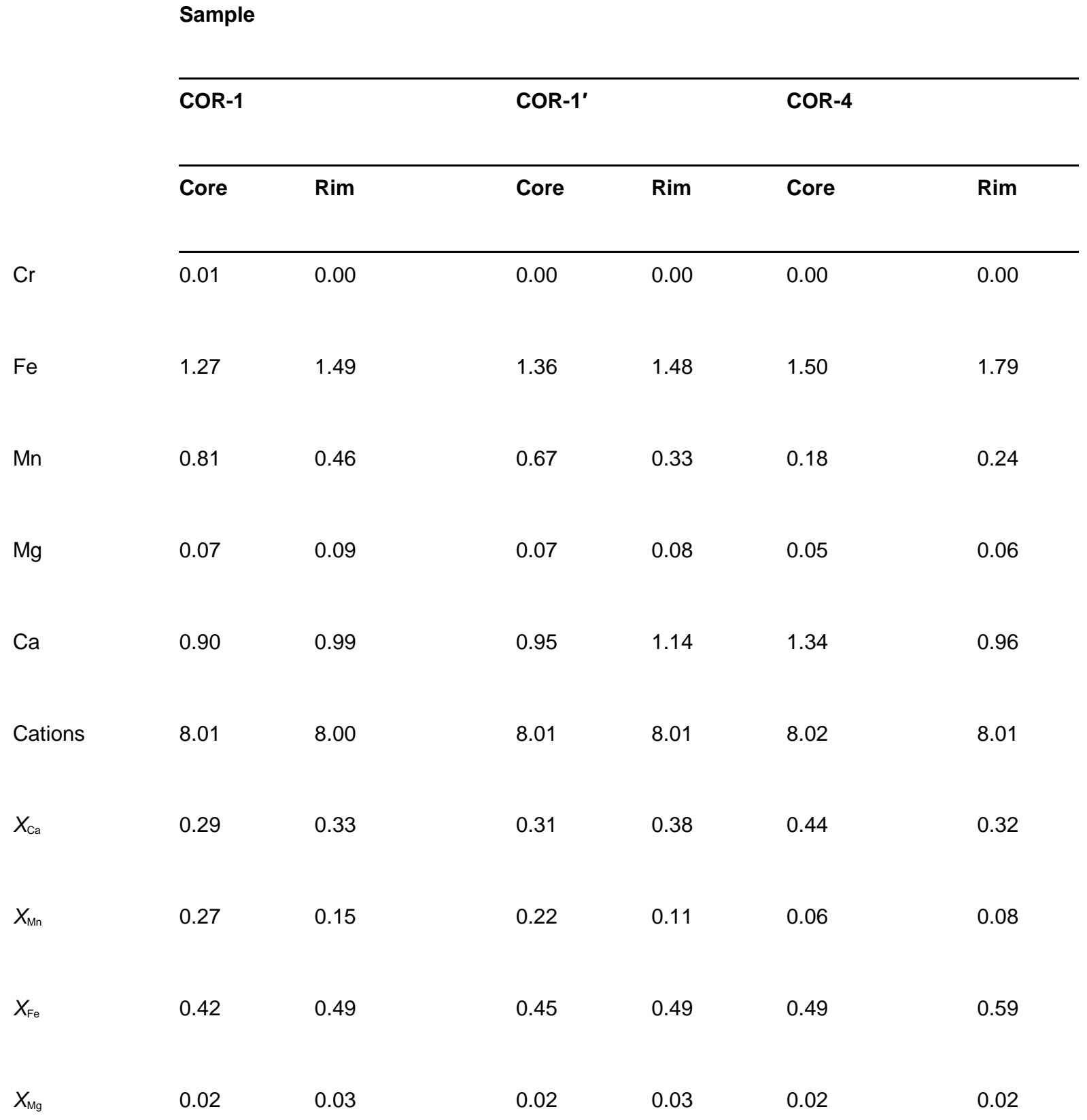

Table 2. Selected clinopyroxene analyses.

COR-1

COR-1'

COR-4

\begin{tabular}{llll}
\hline Incl & Matrix Inc & Matrix Incl & Matrix
\end{tabular}

Core Mantle Rim Rim Core Rim Rim Core MantleRim Core Rim Core Mantle Rim 
Table 1. Selected garnet analyses.

\section{Sample}

COR-1 COR-1' COR-4

\begin{tabular}{lllll}
\hline Core & Rim & Core & Rim & Core
\end{tabular}

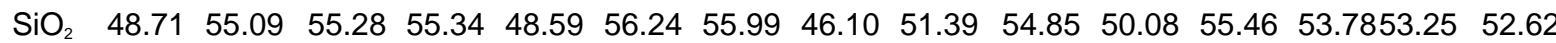

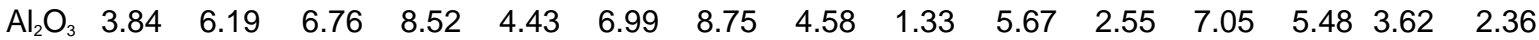

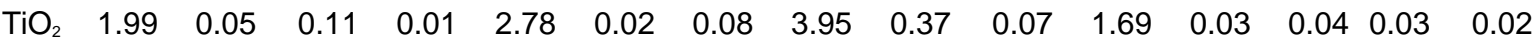

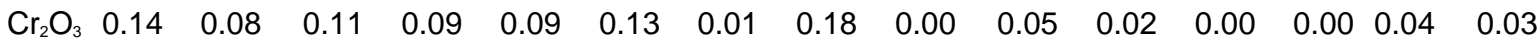

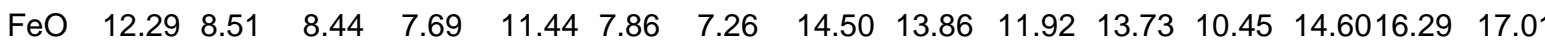

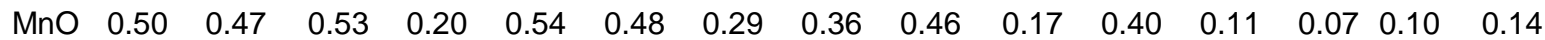

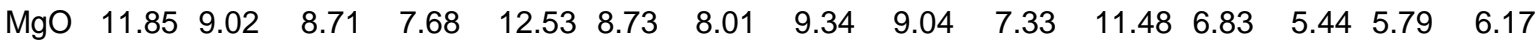

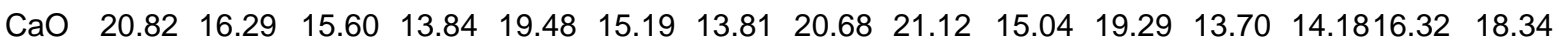

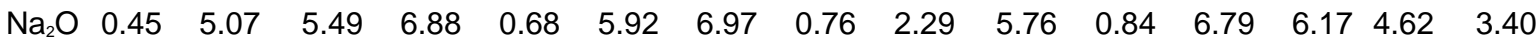

100.59100.77 101.02100.25100.56101.57100.17100.4499.86 100.86100.09100.4299.77100.05 100.08

4 cations, 6 oxygen

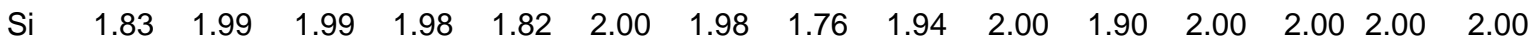

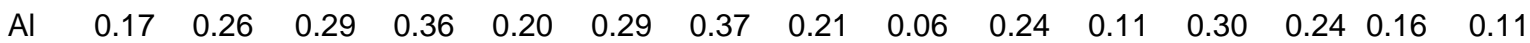

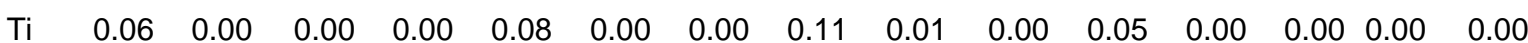


Table 1. Selected garnet analyses.

\begin{tabular}{|c|c|c|c|c|c|c|c|c|c|c|c|c|c|c|c|}
\hline & & & mple & & & & & & & & & & & & \\
\hline & & & $R-1$ & & & & & R-1' & & & & $R-4$ & & & \\
\hline & & & re & & & & & re & & & & re & & $\mathbf{R i}$ & \\
\hline $\mathrm{Cr}$ & 0.00 & 0.00 & 0.00 & 0.00 & 0.00 & 0.00 & 0.00 & 0.01 & 0.00 & 0.00 & 0.00 & 0.00 & 0.00 & 0.00 & 0.00 \\
\hline $\mathrm{Fe}^{3+}$ & 0.08 & 0.11 & 0.11 & 0.15 & 0.06 & 0.11 & 0.14 & 0.09 & 0.20 & 0.17 & 0.06 & 0.16 & 0.21 & 0.17 & 0.14 \\
\hline $\mathrm{Fe}^{2+}$ & 0.30 & 0.15 & 0.14 & 0.08 & 0.30 & 0.13 & 0.07 & 0.37 & 0.24 & 0.20 & 0.38 & 0.15 & 0.24 & 0.34 & 0.40 \\
\hline $\mathrm{Mn}$ & 0.02 & 0.01 & 0.02 & 0.01 & 0.02 & 0.01 & 0.01 & 0.01 & 0.01 & 0.01 & 0.01 & 0.00 & 0.00 & 0.00 & 0.00 \\
\hline $\mathrm{Mg}$ & 0.66 & 0.49 & 0.47 & 0.41 & 0.70 & 0.46 & 0.42 & 0.53 & 0.51 & 0.40 & 0.65 & 0.37 & 0.30 & 0.32 & 0.35 \\
\hline $\mathrm{Ca}$ & 0.84 & 0.63 & 0.60 & 0.53 & 0.78 & 0.58 & 0.52 & 0.85 & 0.86 & 0.59 & 0.78 & 0.53 & 0.56 & 0.66 & 0.75 \\
\hline $\mathrm{Na}$ & 0.03 & 0.35 & 0.38 & 0.48 & 0.05 & 0.41 & 0.48 & 0.06 & 0.17 & 0.41 & 0.06 & 0.48 & 0.44 & 0.34 & 0.25 \\
\hline$\sum$ Cat & 4.00 & 4.00 & 4.00 & 4.00 & 4.00 & 4.00 & 4.00 & 4.00 & 4.00 & 4.00 & 4.00 & 4.00 & 4.00 & 4.00 & 4.00 \\
\hline Mg\# & 68.7 & 76.3 & 76.8 & 83.8 & 69.9 & 78.4 & 85.4 & 58.8 & 68.2 & 67.1 & 63.2 & 70.8 & 55.4 & 48.5 & 46.7 \\
\hline $\mathrm{Jd}$ & 0 & 25 & 27 & 33 & 0 & 30 & 34 & 0 & 0 & 24 & 0 & 31 & 23 & 17 & 11 \\
\hline$A c$ & 8 & 11 & 11 & 15 & 6 & 11 & 14 & 9 & 20 & 17 & 6 & 16 & 21 & 17 & 14 \\
\hline Ca-p & $\times 92$ & 65 & 62 & 52 & 94 & 59 & 52 & 91 & 80 & 59 & 94 & 52 & 55 & 66 & 75 \\
\hline
\end{tabular}

Table 3. Selected analyses of lawsonite, chlorite, phengite, amphibole, albite and titanite.

Sample 


\begin{tabular}{|c|c|c|c|c|c|c|c|c|c|c|c|c|c|}
\hline \multicolumn{5}{|c|}{ COR-1 } & \multicolumn{3}{|c|}{ COR-1' } & \multicolumn{6}{|c|}{ COR-4 } \\
\hline Lws & Lws & Chl & Chl & Ttn & Lws & Glc & $A b$ & $\mathrm{Hb}^{\mathrm{EDS}}$ & $A b^{E D S}$ & Lws & $\mathrm{Chl}^{\mathrm{EDS}}$ & Phn & Fe-Glc \\
\hline In & Matrix & In & Matrix & Matrix & In & $\mathrm{Sec}$ & Sec & In & In & Matrix & Matrix & Vein & Vein \\
\hline \multicolumn{14}{|c|}{$X_{\mathrm{Fe}^{3+}}=\mathrm{Fe}^{3+} /\left(\mathrm{Fe}^{3+}+\mathrm{Al}\right)$} \\
\hline & $\mathrm{e}_{2} \mathrm{O}_{3}$ & & & & & & & & & & & & \\
\hline
\end{tabular}

